\title{
Research of Smart and Remote Sprinkler System for Lawn
}

\author{
Yingying Yin ${ }^{\mathrm{a}}$, Xiuying Li \\ Ji Lin Agriculture University, Changchun, China \\ a yingyingyin_2003@126.com
}

Keywords: Smart turf grass maintenance system, Turf grass irrigation, Remote control.

\begin{abstract}
To irrigate lawn remotely and more smartly, and to solve the problems in the traditional manual sprinkler of lawn, a smart sprinkler system of turf grass has been developed. The smart sprinkler control system was created by researching the characters of lawn, such as water demand, heat resistance and diseases law. And the embedded control system can apply the strategy to irrigate intelligently. Tying the urban lawn features, the system was based on the Internet of things, which simplify the user's control and management. Finally, the experimental results show that the system has the advantages of good effect, low cost, high reliability, easy maintenance, etc. and it will meet the demand of energy saving and environmental protection.
\end{abstract}

\section{Introduction}

Lawn is an important part of urban landscape green. Reasonable maintenance of lawn will save lots of water resource and keep it green for a long time. Now, most of the lawns are irrigated artificially, ${ }^{[1]}$ and when irrigating, much water were wasted, so, developing a water-saving and automatic irrigation system is imperative ${ }^{[2]}$.

We researched the characters of lawn, such as water demand, heat resistance and diseases law, according these laws, design a smart irrigation strategy. In lawn, there is usually less wire and enough sunshine, ${ }^{[3]}$ so we decide to use solar energy to provide energy for our system.

\section{Overall framework}

To meet energy-saving and emission-reduction, smart control, information-based management, easy maintenance and low cost requirement, the system researched 3 key technologies mainly.

The first key technology is irrigation strategy, we made the irrigation strategy by research the growth law of lawn ${ }^{[4]}$, in this way, we can ensure there are enough water for the lawn growth and avoid unnecessary waste of water at the same time ${ }^{[5]}$.

The second key technology is how to supply energy for the irrigation system, in cities, lawn has large area, if we use electric as energy, it will be hard to lay electrical wires, in this system, we use solar energy and lithium battery as the energy source, in this way, the system could run independently and easy to maintenance.

The third key technology is remote control, we adopted the Internet of things to compose all nodes to a complete system.

\section{Planning of irrigation strategy}

According the growth law of lawn and the external environment to plan the irrigation strategy will ensure there are enough water for the lawn growth and avoid unnecessary waste of water ${ }^{[6]}$. This research use Kentucky bluegrass as research object, study on their water demand, heat resistance and diseases law. ${ }^{[7]}$ 


\section{Heat resistance of Kentucky bluegrass}

When the external environment temperature is high, the leaf of Kentucky bluegrass will be hurt, the permeability of leaf cells will be improved, salt and organic materials will ooze ${ }^{[8]}$, the conductivity of tissue soaking solution will change also, so we can get the degree of injury through measuring conductivity.

We got the leaf conductivity in different temperatures for 1 hour, it is shown in table 1.

Table 1 The leaf solution conductivity in different temperatures.

\begin{tabular}{|c|c|}
\hline Temperature $/{ }^{\circ} \mathrm{C}$ & Conductivity/\% \\
\hline 25 & 9.7 \\
\hline 35 & 24.5 \\
\hline 45 & 72.2 \\
\hline
\end{tabular}

As shown in table 1, with the increasing of temperature, the injury of leaf increased, too. So, in the hot summer, we should cool the lawn to ensure its normal growth.

\section{Water demand of Kentucky bluegrass}

Sufficient water supply can ensure the better quantity of lawn, but it is not the more the better, too much more water will restrain the growth of Kentucky bluegrass, Fig.1 shows the relationship between field water capacity and lawn quantity.

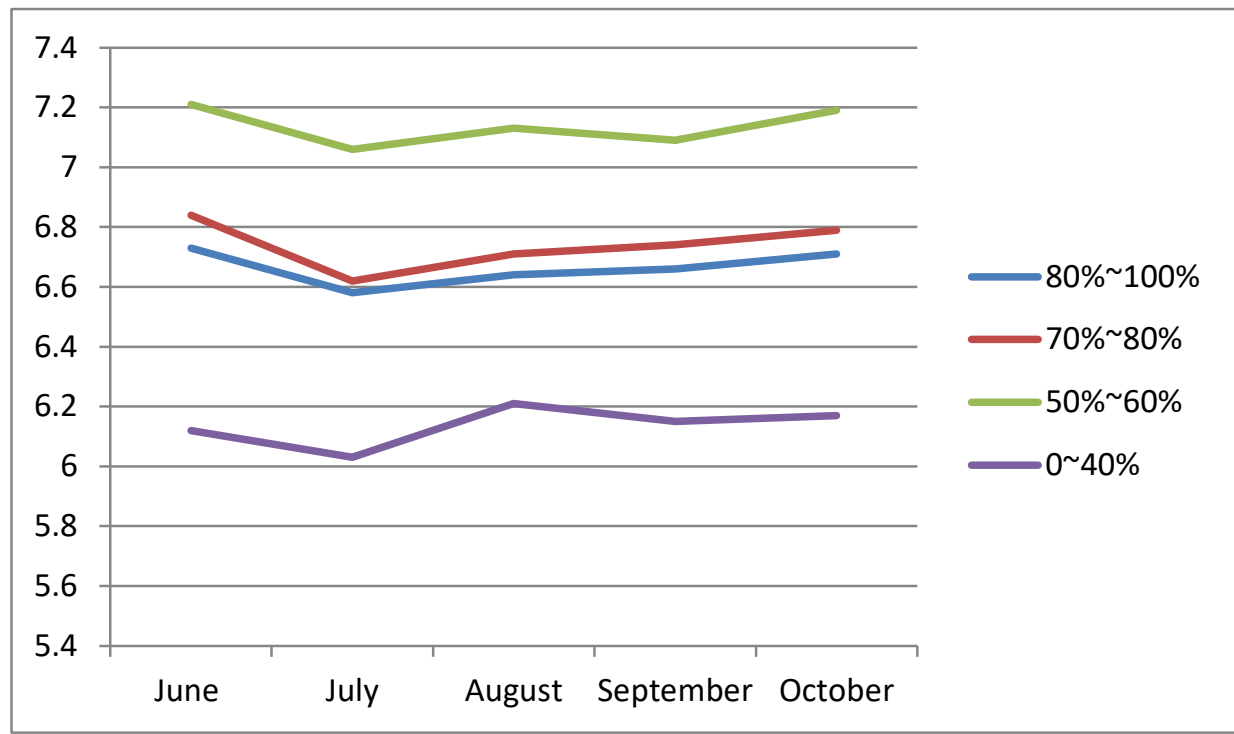

Fig. 1 variation of bluegrass appearance under different field water capacity conditions

As shown in Fig.1, under conditions of $60 \%$ 80\% field water capacity, Kentucky bluegrass growth healthy and the lawn quantity is best.

\section{Irrigation strategy}

According to the research result above, the strategy of irrigation is:

(1)If field water capacity lower than $60 \%$, irrigating the lawn to keep field water capacity is between $60 \% \sim 80 \%$.

(2)When the temperature is too high, irrigating the lawn to low the temperature, to keep the normal growth of Kentucky bluegrass.

(3)All the irrigating actions are carried out in the daytime, to avoid pest. 


\section{Design of remote irrigation system}

\section{Hardware design}

According to the irrigating strategy, the hardware of remote irrigation system is measuring field water capacity and air temperature, pass the value to control centre of the system by wireless sensors, then the software system will decide the lawn need to be irrigated or not, if need, calculate the value of irrigation, and then open or close the solenoid valve, control irrigation. The hardware system structure frame is shown in Fig. 2.

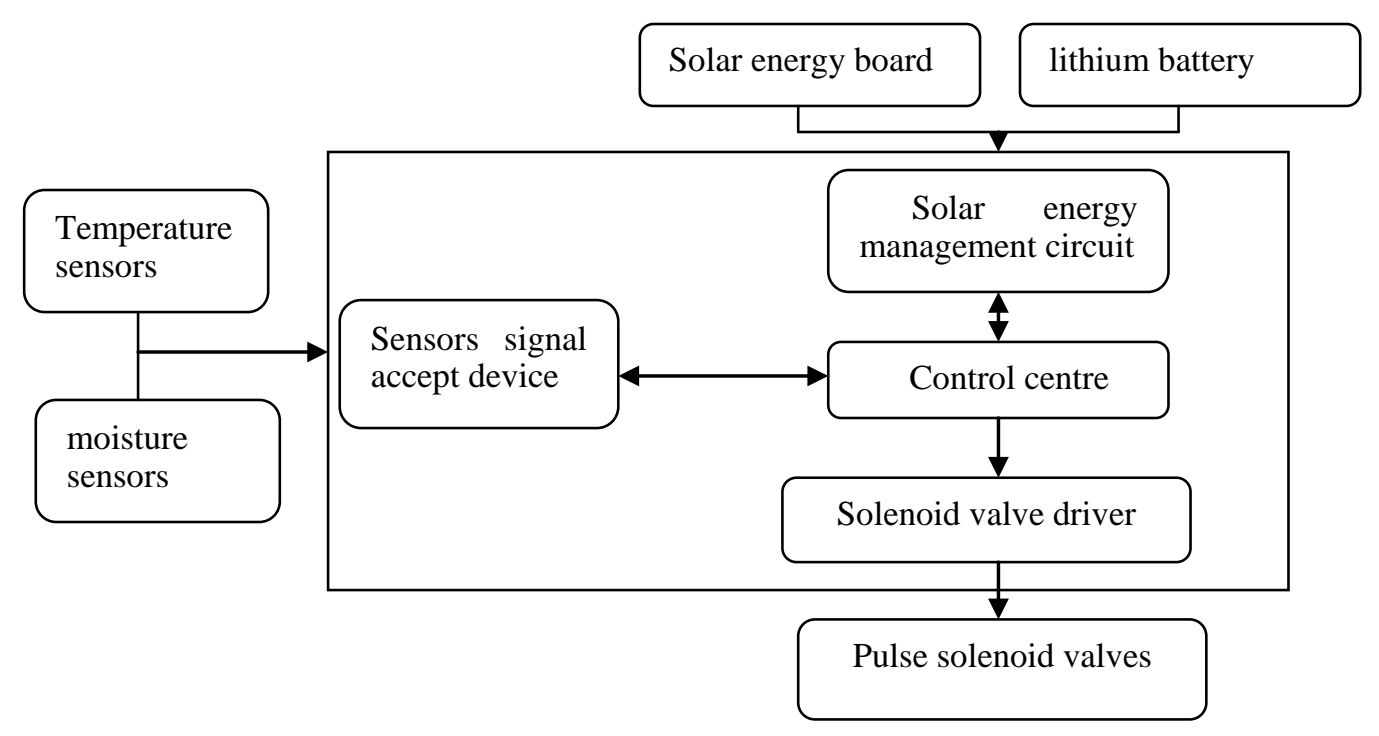

Fig. 2 Hardware block diagram of remote smart control system

\section{Software design}

The irrigation system software is composed of irrigation strategy and solar energy management.

\section{Irrigation strategy algorithm design}

The field water capacity values that pass back by wireless sensors should be transformed to water quality of soil.

Under the conditions that field water capacity is $60 \% \sim 80 \%$, the water quality of soil is calculated by formula(1).

$\mathrm{M}_{\text {Water }}=\left(80 \% \mathrm{~F}_{\mathrm{c}}-60 \% \mathrm{~F}_{\mathrm{c}}\right) \cdot \rho_{\text {water }} \cdot \mathrm{V}_{\text {soil }}$

In formula(1), $M_{\text {Water }}$ is the water quantity, $V_{\text {soil }}$ is the volume of soil, $F_{c}$ is field water capacity, $\rho$ water is the density of water. And then, the soil moisture content is:

$\mathrm{S}_{\mathrm{WC}}=\left(\mathrm{M}_{\text {water }} / \mathrm{M}_{\text {soil }}\right) \cdot 100 \%=\left(\mathrm{M}_{\text {water }} /\left(\rho_{\text {soil }} \cdot \mathrm{V}_{\text {soil }}\right)\right) \cdot 100 \%$

In formula(2), $S_{W C}$ is the soil moisture content, $\rho$ soil is the density of dry soil.

\section{Solar energy management}

When the amount of electricity in lithium battery is lower than $20 \%$, it should be recharged.

\section{Analysis of test result}

All the child nodes composed of the whole irrigation system, the user can keep watch on the work situations on the endpoints, the users also can control child nodes by the end points. The irrigations system adopted sprinkler irrigation method, the amount and uniformity of irrigation can be controlled, so the water lose by surface runoff and deep permeability are both avoided, the utilization of water is improved. The smart remote control irrigation system will save about 53.1\% water than before. 


\section{Conclusions}

Take Kentucky bluegrass and its lawn as the object of study, make a suitable smart irrigation strategy, and then develop a smart remote sprinkler system for lawn, the whole system use solar energy to supply energy, use Internet of things to connect and communicate child nodes. The smart and remote irrigation system has been optimised irrigation method, energy supply method and management method. The test result shows that the system we developed has many advantages such as energy-saving and emission-reduction, smart irrigation, remote control, save energy, easy for installing, lower price, etc. It provides a new smart thought for agriculture irrigation and urban green land maintenance.

\section{Appendix}

Fund Project: The task from the "The 13th Five-year" science and technology projects in Jilin Province Department of Education, [2016] Number 172nd.

\section{References}

[1] Liu Junyan, Zhang Haihui, Hu Jin, et al. Design and implementation of greenhouse automatic irrigation system based on ZigBee(2012) Journal of Agricultural Mechanization Research,1, 111114.

[2] Suhinthan M, Saman K. (2011) Management of orphaned-nodes in wireless sensor networks for smart irrigation systems. IEEE Transactions on signal processing, 10,4909-4922

[3] Coates W, Delwiche J. (2009) Wireless mesh network for irrigation control and sensing. Transacations of the ASABE,52,971-981.

[4] Abraham M, Meyer A, Bonos A, et al. (2008) Differential responses of hybrid bluegrass and Kentucky bluegrass to drought and heat stress. Hort science, 7, 2191-2195.

[5] Jiang Pengjun, Sun Yan. (2009) Studies on effects of physical cooling on heat-tolerance of kentycky bluegrass. Northern Horticulture, 3,184-186.

[6] Perdom P, Murphy J, Berkwitz G. (1993) Physiological changer associated with performance of Kentucky bluegrass cultivars during summer strss. Hort Science, 7, 1182-1186.

[7] Li Wenyan. (2011) Design of wireless water-saving irrigation system based on solar energy. IEEE International Conference on Automation and Systems Engineering Singapore, 1-4.

[8] Zhao Jiong, Tang Qiang, Zheng Cheng, et al. (2010) Design and research on control circuit of electricity-saving and timing solenoid valve. Mechatronics, 7, 24-26. 